\title{
Prevalence and Coinfection of Human Immunodeficiency Virus, Hepatitis B Virus, and Hepatitis C Virus in Mabudi Rural Community of Plateau State, Nigeria
}

\author{
Ramyil, M. Seljul ${ }^{1}$; Shik, L. Ponlir ${ }^{2}$; Dafam, D. Dorkur ${ }^{2}$; Jonah Y. Peter ${ }^{1}$; Lar, \\ N. Nimkong ${ }^{3}$; Nimzing, Lohya ${ }^{4,5}$; Durfa, Nandul ${ }^{6}$ \\ 1. Department of Med. Microbiology and Parasitology College of Health Sciences Bingham University Jos, \\ Nigeria \\ 2. Faculty of Medical Sciences University of Jos, Nigeria \\ 3. Department of Family Medicine, Jos University Teaching Hospital (JUTH) Jos, Nigeria \\ 4. Department of Medical Microbiology University of Jos, Nigeria \\ 5. Department of Laboratory Services AIDS Prevention Initiative in Nigeria Jos University Teaching Hospital \\ (JUTH), Nigeria \\ 6. Anti-Snake Venom Abuja, Nigeria
}

\begin{abstract}
HIV globally. Out of which $22.5 \mathrm{~m}$ were in subSaharan Africa and about $3 \mathrm{~m}$ in Nigeria. In Plateau state, there was a continuous decline in HIV prevalence rates from 11.3\%-3.35\% (2001 to 2008) recorded and a sharp rise to $7.7 \%$ in 2010. Hepatitis B/C virus infection with a prevalence of $15.1 \%$ and $6.0 \%$ are endemic in Nigeria which could lead to chronic liver cirrhosis and cancer with high mortality and morbidity rates. This study aimed at determining the prevalence and coinfection rates of HIV, Hepatitis B and $C$ in a rural community setting of Plateau State. After counselling and obtaining consent from 250 participants, screening for HIV, HBsAg and Anti-HCV was done. WHO/CDC national algorithm of serial testing was employed for HIV antibody. Determination of HBsAg and Anti-HCV were done using rapid test kits. Of the 250 screened specimens, 6(2.4\%) were positive for HIV, 55(22.0\%) for $\mathrm{HBSAg}$ and $31(12.4 \%)$ for Anti-HCV respectively. Coinfection rates of HIV/HBsAg/Anti-HCV was 1(0.4\%),HIV/HBsAg was 2(0.8\%) and HBsAg/Anti-HCV was 6(2.4\%).For HIV, both sexes were equally affected with prevalence of $1.2 \%$ each, while for HBsAg the males showed higher prevalence of 34(13.6\%) than the females 21 (8.4\%).However, the prevalence of Anti-HCV was higher in the females with 18(7.2\%) than in the males $13(5.2 \%)$.The highest prevalence rates of HIV/HBsAg/Anti-HCV were observed in the age group of 2039(2.0\%);10-39(17.6\%); 30-59(8.4\%). Significant P. values of 0.07, 0.9 (1.0 appx) and 0.02 for HIV, HBsAg and Anti-HCV were observed in this study. From this study, the Langtang South HIV prevalence rate has dropped from 9.7\% reported in 2008 to $2.4 \%$ which is lower than the National HIV prevalence rate reported for rural settings in North Central Zone of Nigeria. This may be attributed to numerous interventions, policies, actions towards universal access to HIV prevention, treatment and care. However, the high rates of Hepatitis $B / C$ virus may warrant focusing on adequate care and treatment of infected individuals.
\end{abstract}

Key word: Coinfection, HIV, Viral Hepatitis, Mabudi Rural Community, Langtang South, Plateau State

\section{Introduction}

Globally, the pandemic of HIV and AIDS has continued to constitute serious public health and socio economic challenges for more than two decades ${ }^{(1)}$. Today, about 33.3 million persons were estimated to be infected with HIV ${ }^{(1,2)}$. Of these, 22.5 million $(68 \%)$ were in Sub-Saharan Africa and about 3.0 million in Nigeria ${ }^{(3)}$. This therefore makes Nigeria the second highest after South Africa with number of people living with HIV in the world ${ }^{(2,4,7)}$. The national declines in HIV incidence in populations shows that sustained investigations and increased political leadership for the AIDS response are paying. In the last ten (10) years, the landscape of national HIV epidemics has changed dramatically for the better in most countries especially in Sub-Saharan Africa with fewer new HIV infections across the world in 2011 than $2001^{(3,)}$. In Plateau State, there was a continues decline in HIV prevalence rates from $11.3 \%$ to $3.35 \%$ from 2001 to 2008 recorded and then a sharp rise to $7.7 \%$ in $2010^{(4)}$.

HIV/AIDS remains one of the major challenges to public health in the world today ${ }^{(5,6)}$. Establishing the burden of the infection and the risk factors that contribute to its spread is a key to finding and instituting appropriate intervention strategies to curtail the spread of the disease ${ }^{(5)}$.

Hepatitis B is a major disease of serious global public health proportion; It is preventable with safe and effective vaccines that have been available since $1982^{(8,9)}$. Of the 2 billion people who have been infected with the 
hepatitis B virus (HBV) globally, more than 350 million have chronic (lifelong) infections. Over 20 million people are infected annually with this virus ${ }^{(10-12)}$.

Hepatitis $\mathrm{C}$ is a viral infection of the liver and is the most common blood-borne (direct contact with human blood) infection ${ }^{(11,13)}$. The major causes of $\mathrm{HCV}$ infection worldwide are use of unscreened blood transfusions, and re-use of needles and syringes that have not been adequately sterilized ${ }^{(14)}$. The world health organization (WHO) estimates that about $3 \%$ of the world populations (200 million people) have so far been infected with the Hepatitis C virus. Almost 50\% of all cases become chronic carriers and are at risk of liver cirrhosis and liver cancer $^{(10,12,)}$.

HIV and Viral Hepatitis $\mathrm{B} / \mathrm{C}$ are major public health concern and because of shared routes of transmissions, HIV/HCV coinfection and HIV/HBV coinfection or both are common ${ }^{(6,8,11,)}$. Viral Hepatitis B/C virus infections with a prevalence of $15.1 \%$ and $6.0 \%$ respectively are endemic in Nigeria and could lead to chronic liver disease, cirrhosis and cancer with high mortality and morbidity rates ${ }^{(7,9,14)}$.

\section{Knowledge, Attitudes, and Behaviors about HIV and Viral Hepatitis.}

AIDS cases are becoming visible in Nigeria with at least one out of every four persons had seen someone with HIV or known someone who die of AIDS ${ }^{(7,13,)}$. However, mortality and morbidity rates of viral hepatitis $\mathrm{B}$ and $\mathrm{C}$ infections are on the increase with high prevalence of $15.1 \%$ and $6.0 \%{ }^{(14)}$. Awareness of HIV/AIDS was generally very high $(93.8 \%)$ while viral hepatitis still remains silent. However, correct knowledge of all the routes of HIV, Hepatitis B virus and Hepatitis C virus infections transmissions and two methods of preventions haves remain ${ }^{(11,13,16)}$.

\subsection{Socio-demographic Profile of Langtang South}

Langtang South local government was created on August $21^{\text {st }}, 1991$ and was one of the only three settlement areas that were established to accommodate and resettle Ex-service Second World War veterants in the year 1948. The local government area has 15 electoral wards with Mabudi as its headquarters and has an area of 838 square kilometer $\left(\mathrm{km}^{2}\right)$ " $88^{\circ} 38^{\prime} \mathrm{N}, 9^{\circ} 47^{\prime} \mathrm{E}$ " with a population of 106,305 as at 2006 census. The Taroh people are the main ethnic group in Langtang South with other minority tribes who are mainly Christians with the revenue driven mainly from Agriculture and other sources in mineral like Barytes and Clay ${ }^{(17)}$.

\subsection{Aim and Objective}

a) To determine the prevalence and coinfection rates of HIV, HBsAg and Anti-HCV in Mabudi rural Community of Plateau State.

b) To access the knowledge and risk factors of HIV, HBsAg and Anti-HCV diseases in Mabudi rural community of Plateau State.

\section{Material and Method}

The study population considered was of age ranging from $5-79$ years old of Mabudi rural community of Plateau State, Nigeria. After counseling and obtaining consent from 250 participants, they were then recruited and screened for $\mathrm{HIV}, \mathrm{HBsAg}$ and Anti-HCV. WHO/CDC national algorithm of serial testing was employed for HIV antibody using Determine, Uni-Gold, and Stat-Pak. HBsAg and Anti-HCV was also determined using rapid test kits from Micropoint Bioscience Inc. Santa Clara, Califonia.

\subsection{Laboratory Screening}

$\mathrm{HIV}$, HBsAg and Anti-HCV testing was conducted only by qualified Laboratory Scientists as blood specimens were collected from the participants into EDTA tubes in step by step serial algorithm for HIV. Nonreactive specimens were reported as NEGATIVE. Reactive specimens were confirmed with Uni-Gold HIV test kit. While reactive with both Determine and Uni-Gold were reported as POSITIVE. However, the same blood specimens were screened for viral hepatitis B and C respectively using a one-step rapid test kits (Micropoint) and results recorded.

\section{Results}

Out of the 250 participants, 6 (2.4\%) were positive for HIV; 55 (22.0\%) for HBsAg and 31 (12.4\%) for Anti-HCV respectively. Coinfection rates of HIV/HBsAg/Anti-HCV was $1(0.4 \%) ; \mathrm{HIV} / \mathrm{HBsAg}$ was $2(0.8 \%)$ and HBsAg/Anti-HCV was 6 (2.4\%), both sexes were equally affected with prevalence of $1.2 \%$ each; While for HBsAg the males showed higher prevalence of $34(13.6 \%)$ than the females $21(8.4 \%)$. However, the prevalence of Anti-HCV was higher in the females with 18 (7.2\%) than in the males with $13(5.2 \%)$. The highest prevalence rates of HIV, HBsAg and Anti-HCV were observed in the age group of $20-30(2.0 \%)$; 10 $39(17.6 \%)$ and $30-59(8.4 \%)$ respectively. Significant P. values of $0.07,0.9$ and 0.02 for HIV, HBsAg and Anti-HCV with confident interval of $95 \%$ were observed in this study. 
Table 1: Prevalence of HIV, HBsAg and Anti-HCV positivity by Sex

\begin{tabular}{|l|c|c|cc|}
\hline & & & \multicolumn{2}{|c|}{ Total } \\
Infection (s) & Male & Female & No. & $(\%)$ \\
\hline HIV positive & 3 & 3 & 6 & 2.4 \\
\hline HBsAg positive & 34 & 21 & 55 & 22.0 \\
\hline Anti-HCV positive & 13 & 18 & 31 & 12.4 \\
\hline
\end{tabular}

Table 2: HIV, HBsAg and Anti-HCV positivity by age group among females

\begin{tabular}{|c|c|c|c|c|c|c|c|c|}
\hline infection & $\begin{array}{c}\leq 9 \\
(\mathrm{n}=7)\end{array}$ & $\begin{array}{l}10-19 \\
(\mathrm{n}=24)\end{array}$ & $\begin{array}{l}20-29 \\
(\mathrm{n}=22)\end{array}$ & $\begin{array}{l}30-39 \\
(\mathrm{n}=31)\end{array}$ & $\begin{array}{l}40-49 \\
(\mathrm{n}=17)\end{array}$ & $\begin{array}{l}50-59 \\
(\mathrm{n}=14) \\
\end{array}$ & $\begin{array}{l}60-69 \\
(\mathrm{n}=3)\end{array}$ & $\begin{array}{c}>70 \\
(\mathrm{n}=2) \\
\text { No. } \%\end{array}$ \\
\hline HIV positive & - & - & $\begin{array}{ll}1 & 4.5\end{array}$ & $\begin{array}{ll}2 & 6.5\end{array}$ & - & - & - & - \\
\hline $\begin{array}{l}\mathrm{HBsAg} \\
\text { positive }\end{array}$ & 228.6 & $\begin{array}{ll}3 & 2.5 \\
\end{array}$ & $\begin{array}{ll}4 & 18.2\end{array}$ & $\begin{array}{ll}8 & 25.8 \\
\end{array}$ & $\begin{array}{ll}1 & 5.9\end{array}$ & 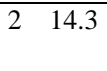 & - & $\begin{array}{ll}1 & 50.0\end{array}$ \\
\hline $\begin{array}{l}\text { Anti-HCV } \\
\text { positive }\end{array}$ & - & $\begin{array}{ll}4 & 16.7\end{array}$ & - & 6.5 & $\begin{array}{ll}4 & 23.5\end{array}$ & $\begin{array}{ll}7 & 50.0\end{array}$ & 33.3 & - \\
\hline
\end{tabular}

Table 3: HIV, HBsAg and Anti-HCV positivity by age group among males

\begin{tabular}{|c|c|c|c|c|c|c|c|c|}
\hline infection & $\begin{array}{c}\leq 9 \\
(\mathrm{n}=7) \\
\text { No. } \%\end{array}$ & $\begin{array}{l}10-19 \\
(\mathrm{n}=24) \\
\text { No. } \%\end{array}$ & $\begin{array}{l}20-29 \\
(\mathrm{n}=46) \\
\text { No. } \%\end{array}$ & $\begin{array}{l}30-39 \\
(\mathrm{n}=31) \\
\text { No. \% }\end{array}$ & $\begin{array}{l}40-49 \\
(\mathrm{n}=12) \\
\text { No. } \%\end{array}$ & $\begin{array}{l}50-59 \\
(\mathrm{n}=14) \\
\text { No. \% }\end{array}$ & $\begin{array}{c}60-69 \\
(\mathrm{n}=3) \\
\text { No. \% }\end{array}$ & $\begin{array}{c}>70 \\
(\mathrm{n}=2) \\
\text { No. } \%\end{array}$ \\
\hline HIV positive & & & $\begin{array}{ll}1 & 2.2\end{array}$ & $\begin{array}{ll}1 & 3.2\end{array}$ & $\begin{array}{ll}1 & 8.3\end{array}$ & 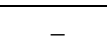 & 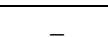 & 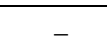 \\
\hline $\begin{array}{l}\text { HBsAg } \\
\text { positive }\end{array}$ & $\begin{array}{ll}1 & 33.3 \\
\end{array}$ & 1238.7 & 1021.7 & 7222.6 & $4 \quad 33.3$ & - & - & - \\
\hline $\begin{array}{l}\text { Anti-HCV } \\
\text { positive }\end{array}$ & $\begin{array}{ll}1 & 33.3 \\
\end{array}$ & $\begin{array}{ll}2 & 6.5\end{array}$ & 4.3 & $\begin{array}{ll}4 & 12.9\end{array}$ & $\begin{array}{ll}4 & 33.3\end{array}$ & - & - & - \\
\hline
\end{tabular}

Table 4: Sociodemographic characteristic of participants

\begin{tabular}{|c|c|c|c|c|}
\hline \multirow[t]{2}{*}{ Characteristics } & \multirow[t]{2}{*}{ Male } & \multirow[t]{2}{*}{ Female } & \multicolumn{2}{|c|}{ Frequency } \\
\hline & & & No. & $(\%)$ \\
\hline \multicolumn{5}{|l|}{$\underline{\text { Age }}$} \\
\hline$\leq 9$ & 3 & 7 & 10 & $(4.0)$ \\
\hline $10-19$ & 31 & 24 & 55 & $(22.0)$ \\
\hline $20-29$ & 46 & 22 & 68 & $(27.2)$ \\
\hline $30-39$ & 31 & 31 & 62 & $(24.8)$ \\
\hline $40-49$ & 12 & 17 & 29 & (11.6) \\
\hline $50-59$ & 5 & 14 & 19 & $(7.6)$ \\
\hline$>60$ & 2 & 5 & 7 & $(2.8)$ \\
\hline Total & 130 & 120 & 250 & $(100)$ \\
\hline \multicolumn{5}{|l|}{ Marital Status } \\
\hline$\overline{\text { Single }}$ & 57 & 50 & 107 & (42.8) \\
\hline Married & 67 & 63 & 130 & $(52.0)$ \\
\hline Widowed & 3 & 2 & 5 & $(2.0)$ \\
\hline Incomplete data & 3 & 5 & 8 & (3.2) \\
\hline Total & 130 & 120 & 250 & $(100)$ \\
\hline \multicolumn{5}{|c|}{ Educational Status } \\
\hline Non-formal & 4 & 21 & 25 & $(10.0)$ \\
\hline Primary & 16 & 29 & 45 & $(18.0)$ \\
\hline Secondary & 72 & 43 & 115 & $(46.0)$ \\
\hline Tertiary & 32 & 24 & 56 & (22.4) \\
\hline Incomplete data & 6 & 3 & 9 & $(3.6)$ \\
\hline Total & 130 & 120 & 250 & $(100)$ \\
\hline \multicolumn{5}{|l|}{ Occupation } \\
\hline House wife & 0 & 21 & 21 & $(8.4)$ \\
\hline Students & 60 & 41 & 101 & (40.4) \\
\hline Farming & 18 & 25 & 43 & (17.2) \\
\hline Business & 20 & 8 & 28 & (11.2) \\
\hline Civil servants & 21 & 17 & 8 & (15.2) \\
\hline Applicants & 6 & 4 & 10 & (4.0) \\
\hline Incomplete data & 5 & 4 & 9 & $(3.6)$ \\
\hline Total & 130 & 120 & 250 & $(100)$ \\
\hline
\end{tabular}




\section{Percentage positive}
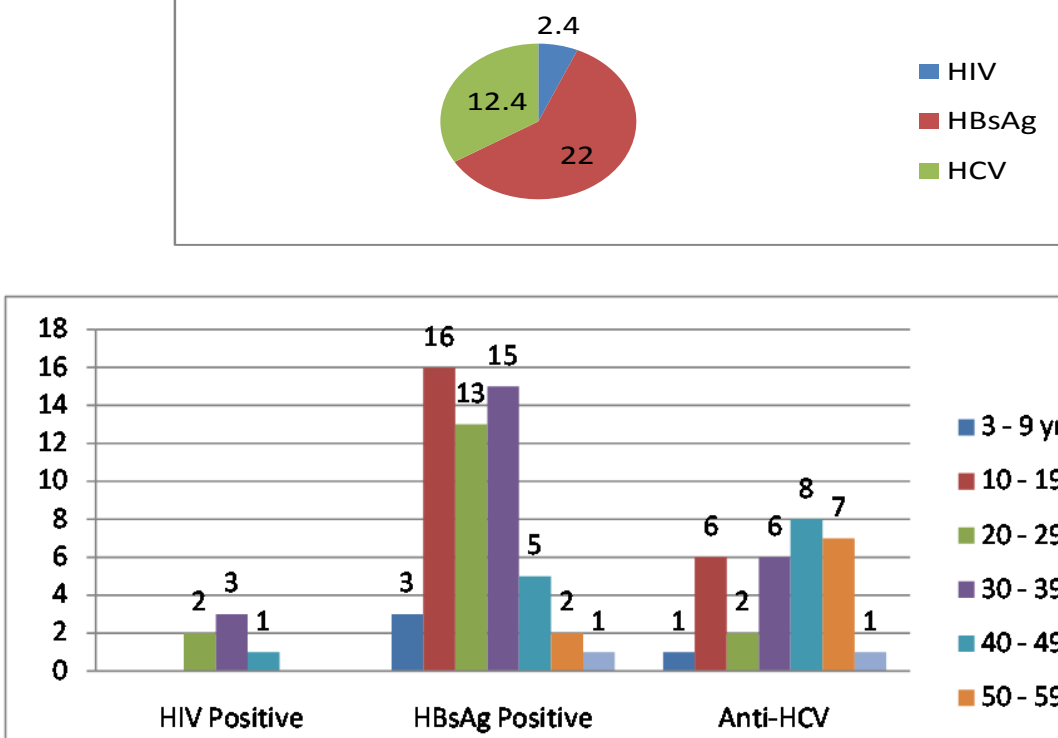

- 3 - 9 yrs

$10-19$ yrs

$20-29 \mathrm{yrs}$

$30-39$ yrs

$40-49$ yrs

$50-59$ yrs

$>60$ yrs

Figure 2: Sero-positivity of HIV, HBsAg and Anti-HCV by age group
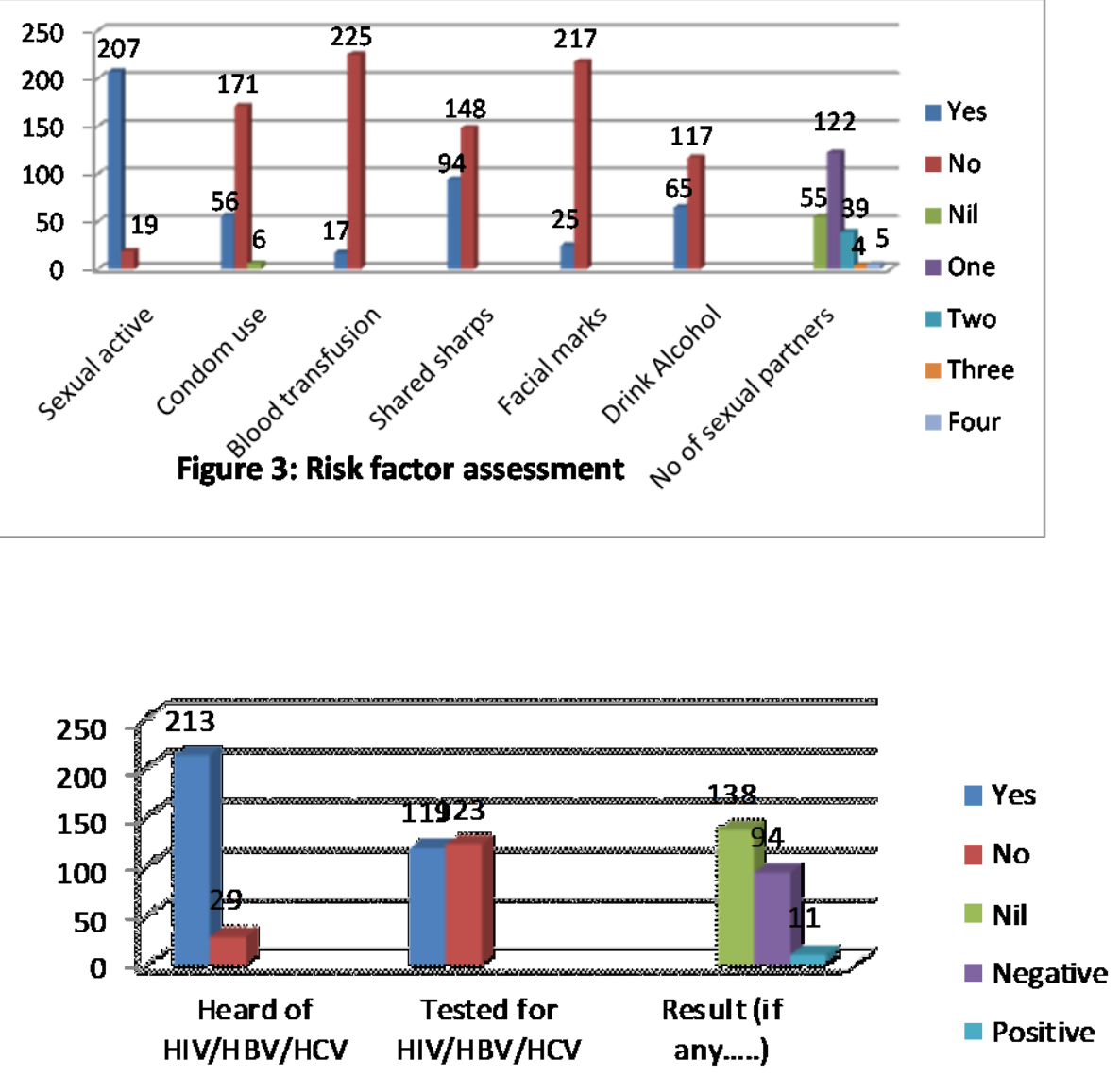

Figure 4: Knowledge assessment of HIV and Viral Hepatitis 


\section{Discussion}

From this study, the Langtang South HIV prevalence rate has dropped drastically from $9.7 \%$ reported in 2008 to $2.4 \%$ which is lower than the National HIV prevalence of $2.7 \%$ reported for rural setting in North Central zone of Nigeria. 22\% prevalence of HBV infection reported in this study was higher than the $10.3 \%$, 12.5\% reported in Jos and Benin by Sirisena ND (2002) and Ugbebor (2011). However, this supported the WHO's report for Nigeria as highly endemic area with prevalence greater than $8 \%$ for HBV. The prevalence of $12.4 \%$ for Anti-HCV in this study was found to be higher when compared with the study in Jos and Benin with $5.2 \%$ and $3.6 \%$. In this, coinfection rates $0.4 \%$ for $\mathrm{HIV} / \mathrm{HBsAg}$ and Anti-HCV was found to be lower than the $11.9 \%, 4.8 \%$ and $1 \%$ reported in Ibadan by Otegbayo (2008) while in Iran, a prevalence of $14.5 \%, 72 \%$ and 7.9\% was recorded by Mohsen (2009). For HIV, both sexes were equally affected with a prevalence of $1.2 \%$ each while for HBsAg the males showed higher prevalence of $13.6 \%$ than females $8.4 \%$; however, Anti-HCV was higher in females with $7.2 \%$ than in males with $5.2 \%$ recorded in our study which is found to be lower than the coinfection rates of $21.2 \%$ in women and $6.7 \%$ in males respectively reported by Mohsen (2009) in Iran. In our study, a lower prevalence rate of HIV, HBsAg and Anti-HCV were observed among age group of 20-39 (2.0\%), 10-39 (17.6\%) and 30-59 (8.4\%) as compared to the one in Iran $77.2 \%$ for less than 30 years and $74.2 \%$ in patients between 31-50 age ranges. Awareness of HIV/AIDS was generally very high (93.8\%) while viral hepatitis still remains silent (Nigeria GARPR 2012). However, correct knowledge of all the routes of HIV, Hepatitis B virus and Hepatitis C virus infections, transmissions and two methods of preventions have remained as compared to our study, $85.2 \%$ have heard of at least one of the viral diseases. $47 \%$ have been tested of either HIV or viral Hepatitis B/C. Alcoholism is responsible for 4,700 deaths per year among young people under the age of $21-29$. David Jermigan (2013) reported that more than $70 \%$ high school students have consumed alcohol, and about $22 \%$ engage in heavy episode drinking as compared to our study found that $26 \%$ drink alcohol this cut across every age group (i.e. $18-49$ years).

\subsection{Conclusion}

From this study, the Langtang South HIV prevalence rate has dropped drastically from 9.7\% reported in 2008 to $2.4 \%$ which is lower than the National HIV prevalence rate reported for rural settings in North Central Nigeria. This may be attributed to the scaling of the numerous interventions, policies, actions towards universal access to HIV prevention, treatment, care and support. However, the high rates of Hepatitis B and C viruses may warrant focusing on adequate care and treatment of infected individuals.

\subsection{Recommendation}

Further studies are needed so as to confirm these findings in HIV, Viral Hepatitis B, and C endemic areas. Diagnosis in HIV / HBsAg / Anti-HCV is vital in order to take care of the high rates of Hepatitis B and C virus may warrant focusing on adequate care and treatment of infected chronic individuals; however, there is a very high demand for hospital laboratory upgrade in the aspect of public health planning and development in Langtang South community of Plateau state Nigeria.

\subsection{Future scope:}

The findings from this study will be used for advocacy to policy makers to improve public health planning, resource mobilization and programme implementation.

\section{Acknowledgement}

Our profound gratitude goes to the Management Committee Chairman Langtang South Local Government Council Hon. Nanman Darko for sponsoring this project; Dr. Fom Dakwak Commissioner Health Plateau State for giving the permission to conduct the project; Dr. Francis Magaji Director Plateau AIDS Control Agency (PLACA) for donating HIV test kits and Langtang South Development Association (LSDA) Jos branch for their financial and moral support.

Special thanks to Mr. Glongshak D. Moses and Mr. Bash Musa Auta who are instrumental for sample collection, analysis, and processing.

We appreciated the indirect and direct contributions of Hon Beni Lar, Hon. Joyce Ramnap, Porf.VM Ramyil, Registrar University of Jos Dr. Jilli; and the community leaders.

We would also like to especially thank the Medical Students and Health workers forum for community mobilization and awareness campaign.

It is our earnest hope that this will be useful for the information, review, planning and decision - making needs of relevant stakeholders to halts and reverse the spread of the epidemic as well as to ensure universal access to prevention, treatment, care and support. 
[1]. UNAIDS World AIDS Day Report 2012.

\section{References:}

[2]. Federal Republic of Nigeria Global AIDS Response Country Progress Report; Nigeria GARPR 2012

[3]. Nigeria National Agency for the control of AIDS. National HIV/AIDS strategic plan 2010 - 2015. Abuja Nigeria: NACA, 2010.

[4]. Nenfort E. Gomwalk; Lohya Nimzing; John D Mawak; Nimzing G. Ladep; Stephen B Dpiap; Demas Damshak; Esther Kim; Christiana Barau; John K Jinung; Bala M Rumtong; Yusuf A Agabi: Sero-epidemiology of human immunodeficiency virus (HIV) in Plateau State. J. infect Dev. Ctries 2012; 6(12): 860 - 869.

[5]. $\quad$ Ramyil MSC; Imade GE; Agbaji O; Hauwa F; Agaba P; MuazuM;Chindak L: Trend of HIV Sero-prevalence in MabudiLangtang South of Plateau State, Nigeria. General Poster Abstract 1 - 1A pdf-University of Ilorin. 567083/NACA/015:2010.

[6]. Federal Ministry of Health [Nigeria]. HIV/STI integrated Biological and Behavioural Surveillance Survey 2007. Abuja Nigeria: Federal Ministry of Health, 2008

[7]. Modi AA, Feld JJ: Viral hepatitis and HIV in Africa. AIDS Rev-2007, 9:25-39

[8]. Leeratanapetih N; Seseagrut W: Hepatitis B virus and Hepatitis C virus coinfection with HIV patients at Khonkaen Hospital. Khonkaen Hospital Medical journal 2008, 30:229-238.

[9]. Siricena ND, Njoku MO, Idoko JA, et al. Carriage rate of HBsAg in an urban Community in Jos, Plateau State Nigeria. Nig Postgrad Med J. 2002; 9:7-10.

[10]. Ramyil,MS; Fadairo,YO.;Fadeware, H;Wuyep,GA.; Ekeh,E.; Lekuk, CI.; Dusu,DC; Badung,BP; Mu'azu,MA.; Agaba, P; Ani,AE; Agbaji, OO.; Sagay, AS.; Imade,GE; Kanki, P. comparison of rapid test and elisa assay for hepatitis B and C diagnosis among HIV positive patients in Jos, Nigeria. Icasa2011.org.

[11]. Mohsen M; Gholamreza T; Ali S; Farzad E; Yadollah P; Ehsan G; Hadis B (2009): Survey of both hepatitis B virus and hepatitis C virus coinfection among HIV positive patients: Virology Journal 2009, 6:202. Doi: 10.1186:1743-422x-6-202.

[12]. Otegbayo JA, Fasola FO, Abaja A. Prevalence of Hepatitis B surface antigen (HBsAg) and Hepatitis B envelope antigens (HBeAg), risk factors of viral acquisition and transminase among blood donors in Ibadan, Nigeria. Trop Gasteroent. 2003; 24: 217-226.

[13]. Ugbebo O; Aigbiror M; Osazuwa F; Ewing GW; Enabudoso O: The prevalence of hepatitis B and C viral infection among pregnant women. North Am. J Med Sci. 2011; 3:238-241.

[14]. Tunde W. et al Population - based estimates of prevalence of HIV, HBV and HCV and HIV - related risk behaviours in male injection drug users in Lagos, Nigeria: Rome, Italy: IAS conference, 2011.

[15]. Strickland GT, HCV in developing countries. Postgrad Doc. (Africa) 2002; 24:18-20.

[16]. David Jernigan: First national survey examining brand preferences among under age youth. Online by Alcoholism: clinical and experimental research. www.camy.org. accessed $11^{\text {th }}$ Feb. 2013

[17]. Plateau State official website and portal/PSGN http:/www.plateau.gov.ng. 